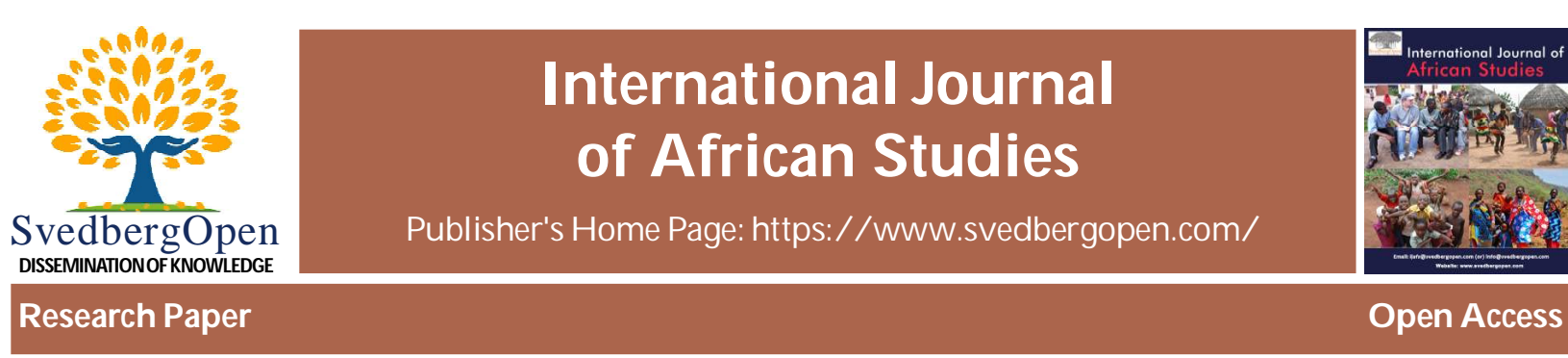

\title{
Reflections on living and dying nations: Space and time in Africa geopolites
}

\author{
Marcel Kitissou $^{1 *}$ \\ ${ }^{1}$ Cornell University, Ithaca, New York, USA. E-mail: mk224@ cornell.edu
}

\section{Article Info}

Volume 1, Issue 1, March 2021

Received : 01 December 2020

Accepted : 12 Febraury 2021

Published : 05 March 2021

doi: 10.51483/IJAFRS.1.1.2021.14-23

\begin{abstract}
This paper is a reflection on the influence of time and space on Africa in geopolitics. It proposes that, while history, in the long-run is perceived as linear, in the short-term it is granular. To make sense of events, one must connect the dots between cluster of times. The analysis builds on the May 1898 statement of the former Prime Minister of the United Kingdom, Lord Salisbury, assessing the geopolitics of his time as made of living nations and dying nations. He characterized the living nations as having the tendency to encroach on the territory of the dying ones. The statement implies a combination of geography and a reference to biological processes with implication of space and the vicissitudes of time involved. The processes of living and dying take time and imply occupying a space. As the living states encroach on the territory of the dying, borders become, beyond their internationally recognized physical demarcations, breathing, and living entities with expanding (or shrinking) virtual borders. This concept is referred to as peri-corporal space in the paper. To test this hypothesis, the United States' international influence and the global status China now enjoys are analyzed. Also, the de facto Franco-African state (Françafrique lost its legitimacy due to a combination of events in the 1990s), as a typical case, is used to illustrate when, why, and how the expansion of one nation's virtual border reduces the margin of action of other states.
\end{abstract}

Keywords: US, China, United Kingdom, France, Africa, Time, Space, Geopolitics

(C) 2021 International Journal of African Studies. This is an open access article under the CC BY license (https://creativecommons.org/licenses/by/4.0/), which permits unrestricted use, distribution, and reproduction in any medium, provided you give appropriate credit to the original author(s) and the source, provide a link to the Creative Commons license, and indicate if changes were made.

\section{Introduction}

The Spanish-United States war at the end of the $19^{\text {th }}$ century ended in the victory of the United States (US). On May 1, 1898, the Manila Bay naval battle lasted just six hours. Every Spain's ship was sunk or captured. The Spanish flagship captain was killed. The shoreside commander committed suicide. Casualties on the US' side? One! Due to heart attack. A $15^{\text {th }}$ century medievalist style empire was fading away. A $1{ }^{\text {th }}$ century civilization was emerging as a global power. ${ }^{1}$

Commenting on the state of the world after the US' victory, the British Prime Minister, Lord Salisbury, in a famous speech at the Albert Hall on May 4, 1898, declared that "One can roughly divide the nations of the world into the living and the dying." The weak nations become increasingly weaker and the strong ones increasingly stronger, Lord Salisbury went on. It was, therefore, understandable that "living nations will fraudulently encroach on the territory of the dying"

\footnotetext{
1 Daniel Immerwhar, How to Hide an Empire: A History of the Greater United States, Picador, New York, 2019 , p. 67.
}

* Corresponding author: Marcel Kitissou, Cornell University, Ithaca, New York, USA. E-mail: mk224@cornell.edu 
(Lindqvist, 1997). ${ }^{2}$ Lord Salisbury was not only referring to non-European countries such as the Ottoman and the Chinese empires, but also to countries within Europe, a typical example being Spain. ${ }^{3}$ To expand that vision, one may add the collapse of the Third Reich and of the Soviet Union in the $20^{\text {th }}$ century. It is an image that comes frighteningly close to reality when one observes the correlation of forces in the contemporary world and the relationships between developed and underdeveloped countries. A typical example is the continuing influence of France in its former colonies in Africa south of the Sahara. Embedded in the metaphor of living and dying nations is an association of geography and biology, thus a combination of space and what Carlo Rovelli (2018) called "the order of time."4

In this essay, the association of physical space and the vicissitudes of time will be examined regarding the life of nations. The hypothesis underlying this discussion is that, like individuals, nations have a peri-corporal space. That virtual space can expand or shrink over time depending on the influence (or lack of influence) of nations in the global power play. To illustrate this concept, examples of great powers such as the US and China will be used, with the de facto Franco-African state (Françafrique) as an illustration.

\section{Time: the familiar stranger ${ }^{5}$}

Time is the least understood of things that are familiar to us. For Aristotle, time is the measurement of change. For Newton, time exists even if there is no change. Einstein reconciled both with the notion of space-time. And, as quantum physicists would have it, time is granular, not linear. Then, sociology of history could consider the interface of time and space in both linear and granular manners depending on the level of analysis. That is what Leo Hamon put into good practice when he wrote Acteurs et données de l'histoire (agents and data of history) (1970). ${ }^{6}$ According to Hamon, it is only after a long period of time that historians discern "movements" in historical evolution. At the same time, within a social setting, not all the components move at the same pace. In the US today, for example, one can observe that law enforcement practices do not match the ideal of equality and that vote suppression measures in certain states contradict the ideal of universal democracy. Furthermore, recurrent Supreme Court's cases about abortion rights are an indication that every generation must renegotiate the meaning of the law. It is the granular interplay and mutual adjustments of subsystems within societies that are described as linear movements in the long run.

Among other authors that studied the phenomenon of time is Carlo Rovelli, the author of The Order of Time (2018). From the point of view of this physicist, time is granular rather than linear. Thus, it is by connecting the dots in clusters of times that we make sense of events. If, for example, we follow the evolving importance of sugar cane plantations, we can explain how, over the course of several centuries, from southern Europe to the Mediterranean islands, to West Africa and to the New World, the sweet spice played an important role in the practice of enslaving first non-Africans, then concentrating on Africans on the West coast of the continent.

J. T. Fraser, in Time, the Familiar Stranger (2012), asserts that “...it is much easier to secure cooperation among people who have no calendars than among people with different calendrical traditions, maintained among other reasons...for the purpose of securing distinct group identities" (p. 315). ${ }^{7}$ In a way, Giordano Nanni, in The Colonization

\begin{tabular}{|c|c|}
\hline Source: & $\begin{array}{l}\text { https://www.google.com/search?q=direction+arrow+sign \& tbm=isch\&source=iu \&ictx=1\&fir=wIS- } \\
\text { Ts56CTG4gM\%252CiPqLI_AIqk5YnM\%252C_\&vet=1\&usg=AI4_- }\end{array}$ \\
\hline Figure & lage representing linear conception of time \\
\hline
\end{tabular}

2 Lidqvist, S., Exterminate All the Brutes, 1992, p.140

3 Rhode, B., "The Spanish Question is Burning": Living and Dying Nations in 1898." Retrieved from https://www.belfercenter.org/ event/spanish-question-burning-living-and-dying-nations-1898 on December 12, 2020.

Carlo Rovelli , The Order of Time, Riverhead Books (2018)

5 J. T. Fraser, Time, the Familiar Stranger. The University of Massachusetts Press, 1987.

Leo Hamon, Acteurs et données de l'histoire, Presses Universitaires de France, 1970

J. T. Fraser, op.cit. p. 315 


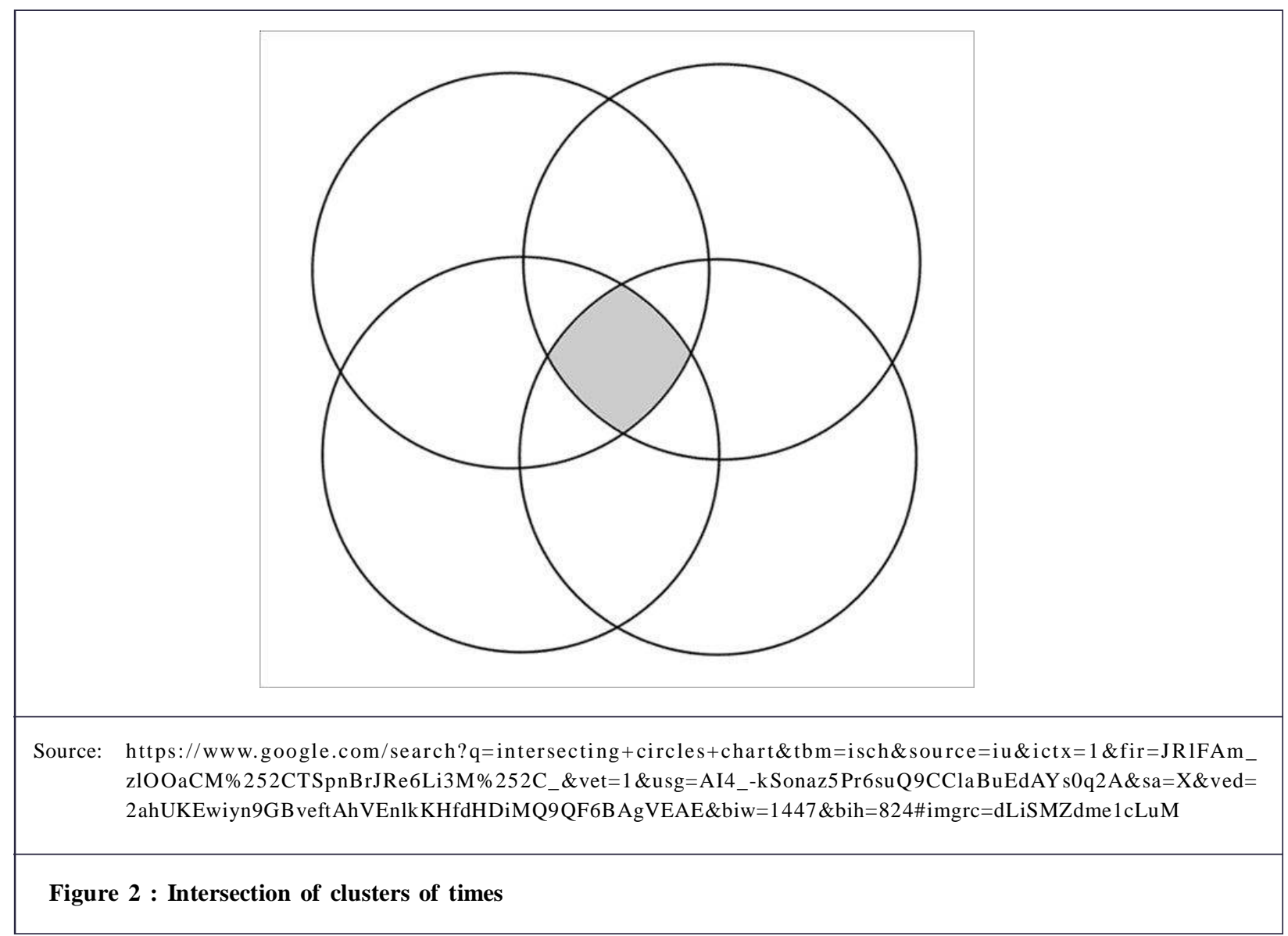

of Time, Ritual, Routine and Resistance in the British Empire (2012), expands the idea of control by showing that Westernization came to Africa, not only in the form of control of space but also, more forcefully, in the form of control of time, imposed by force by the colonial administrators and by persuasion by Christian missionaries. He noted that the Berlin Conference that carved out the African continent among European powers and the establishment of the Greenwich Median Time happened in the same year, 1884. That is, after time had been extracted from nature and put into a machine, the clock, to control the rhythm of life of individuals and societies, prayer, and labor output. Then, the geographical position of London has become associated with the time of reference for the rest of the world. This essay proposes that the influence exercised by great powers combines the control of both the space and time of those subjected to that influence.

This does not mean that nations under domination are passive recipients of hegemonic influence. The struggle against domination, thus resistance to death, reminds one of The Tragic Sense of Life, the title of a book by the Spanish philosopher, Miguel de Unamuno, first published in 1912: in the realm of existential forces, life is the antithesis of reason, hence unpredictable convulsions vs. rational discourse. ${ }^{8}$

\section{Peri-corporal space in theory and practice}

Leonardo da Vinci's (1452-1519) representation of the Vitruvian Man illustrates well the concept of peri-corporal space.

Well before him, pre-Socratic Greek Philosopher, Protagoras of Abdera (490 BC-420 BC), asserted that "Of all things the measure is Man, of the things that are, that they are, and of the things that are not, that they are not." Usually rendered as "Man is the measure of all things," Protagoras' assertion pre-figured existential relativism such as in the works of Kierkegaard (a religious philosopher), Nietzsche (an anti-Christian), Sartre and Camus (both atheists). However, the Vitruvian Man is static. Living human body moves constantly, in space and time. The gymnastic performance below demonstrates an evolving and expansive peri-corporal space.

The peri-corporal space can be related to or depend on physical attributes. The body moves in time and space with changing dimensions of the peri-corporal space. But more than physical space, as a virtual space, it also represents

8 Miquel de Unamuno, The Tragic Sense of Life, 1912 republished by Sophia Omni, 2014. 


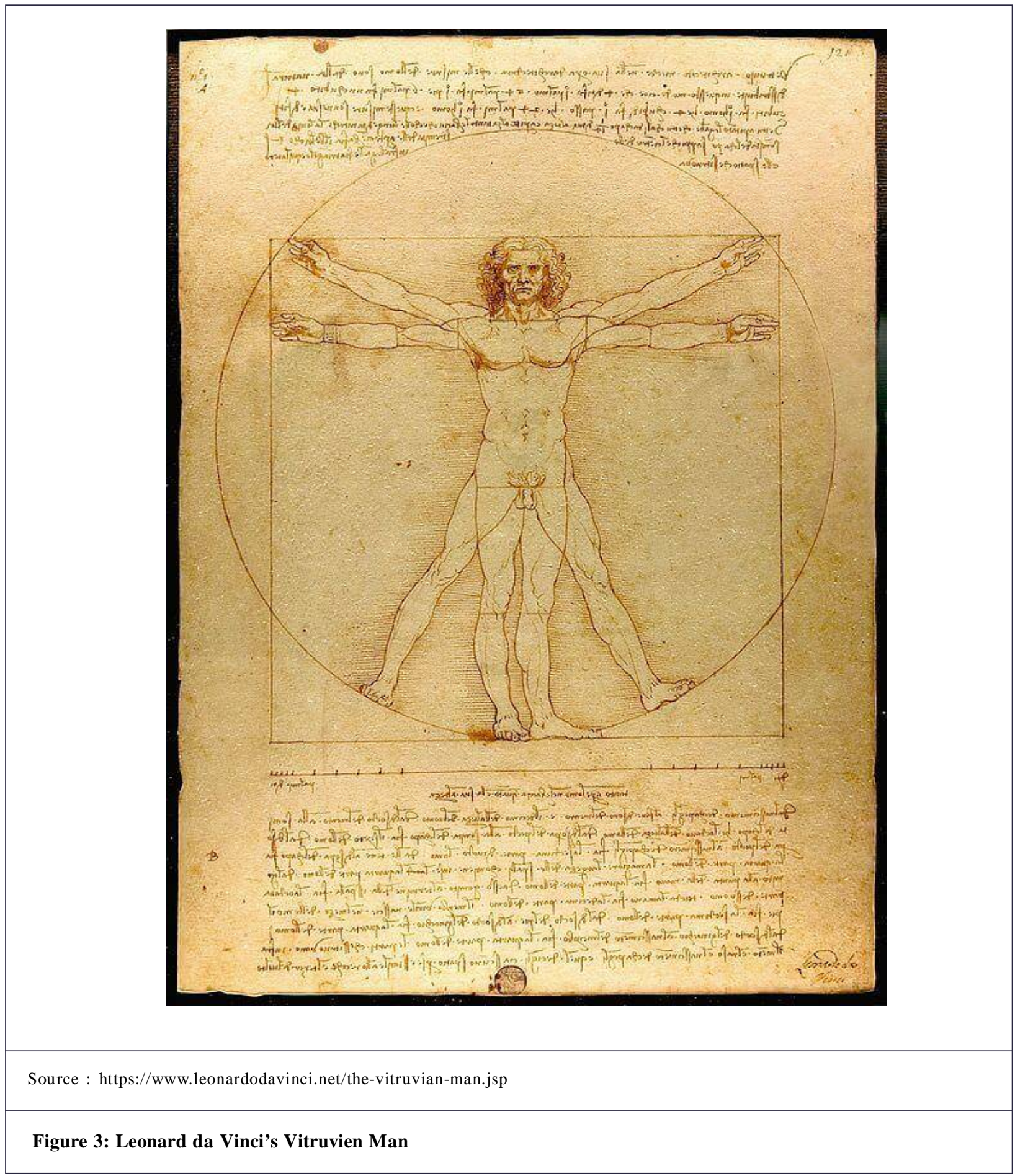

social status. It translates the influence of the individual: social, economic, and political status at a certain point in time and space. It involves the underlining power, conceptualized by Pierre Bourdieu as "symbolic capital."

The same can be said about states. Examples discussed below are the US, China, France and their relationships with Africa.

\subsection{The case of the United States}

What is true for individuals is also true for polities. Borders are not static like the representation of the Vitruvian Man. They are living and breathing entities. The $19^{\text {th }}$ century, as an illustration, was a pivotal time when the living nations were encroaching on the territories of the dying ones. Daniel Immerwhar observes that "What Roosevelt and Turner had noticed was a fact not just about the US, but about the world. For industrializing societies, the $19^{\text {th }}$ century has been one of relatively easy expansion. The US spread west, Russia spread east, and the European powers turned south, toward colonies in Asia and Africa" (2019). 


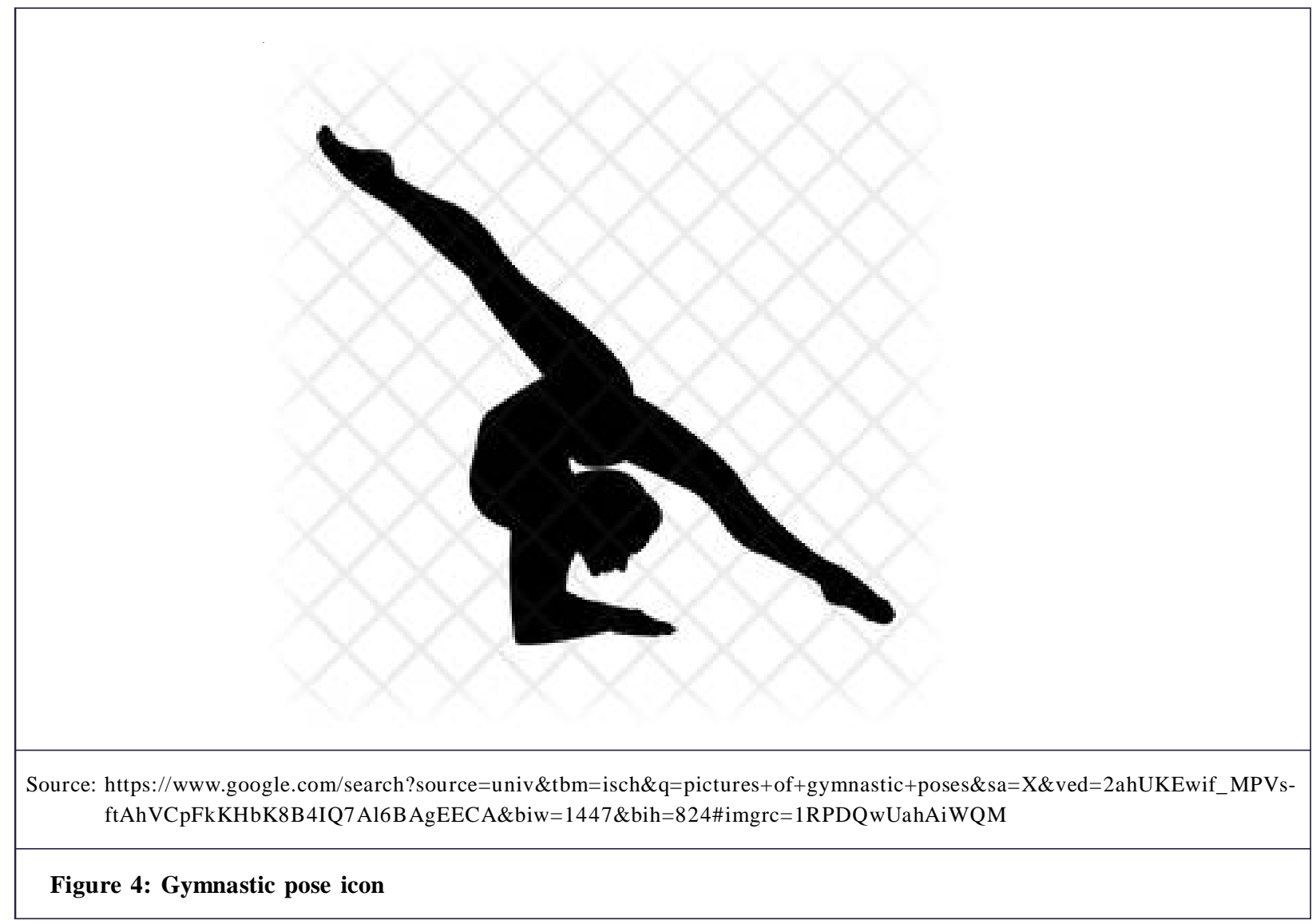

Typical cases of living global powers encroaching on others' territories in today's geopolitics are the US and China. The usual map of mainly the continental US is what is termed logo map. The actual size of the US is much bigger and includes territories in the Caribbean basin and islands in the Pacific:

The next two years [after 1898], 1899-1900, saw the US annexing half of Samoa, another Pacific stronghold that has long been of interest, along with the uninhabited Wake Island.

By the time the shooting stopped and the treaties were ratified, the US had gained more than 700 islands holding 8.5 million people. Counting Alaska, the overseas empire encompassed an area nearly as large as the entire United States had been in 1784 and held a population of more than twice its size. ${ }^{9}$

"This sort of expansion was typical in the nineteenth and early twentieth centuries. When countries get powerful, they generally got bigger" (Immerwhar, 2019): the more they industrialized, the more dependent they were on raw materials from distant locations. After World War II, territorial expansion gave way to a policy of global hegemony. Technological inventions rapidly took place and international institutions were created as structures to back the US' global ambitions. The extra-territoriality of the US dollar is not the least significant example. "After World War II, the US deployed its armed forces abroad 211 times in 67 countries." ${ }^{10}$ And military interventions are to ensure the Pax Americana including in Africa south of the Sahara, particularly with the US. Africa Command created in 2007 and fully operational in 2008 .

\subsection{China}

Modern China, in many respects, is following a cursus honorum after that of the US China considers Taiwan as part of its territory. It is in border dispute with neighboring countries and is claiming many islands in the South China Sea. It has created international organizations outside the US' influence such as the Shanghai Cooperation Organization created in 1996 and currently comprised of eight Member States (China, India, Kazakhstan, Kyrgyzstan, Russia, Pakistan, Tajikistan, and Uzbekistan), four Observer States (Afghanistan, Belarus, Iran, and Mongolia) and six Dialogue Partners (Armenia, Azerbaijan, Cambodia, Nepal, Sri Lanka, and Turkey, a member of NATO). In 2020, China and other nations (from Japan, Australia, New Zealand, South Korea, to Myanmar, and the nations of the Association of Southeast Asian Nations)

9 Daniel Immerwhar, ibid. p. 80.

${ }^{10}$ Daniel Immerwhar, ibid. p. 14 
signed the Regional Comprehensive Economic Partnership (R.C.E.P), one of the world's largest, covering 2.2 billion people. Shaped by Beijing, R.C.E.P is a potential counterweight to US influence in the region and could help, symbolically, cement Beijing's image as the dominant economic power in the region. Furthermore, the ongoing Belt and Road Initiative (BRI) combines both symbolic and practical values. It indicates that China is a global power player in terms of spatial presence. It also has the potential to set the clock for exchanges between China and the rest of the world because it is not enough to have access to raw materials around the world. The supplies should arrive in a timely manner and on a regular basis to avoid disruptions in China's industrial complex. The BRI might be an instrument to synchronize and create a shared "social temporality" between Chinese industries and suppliers around the world, outside the influence of potential adversaries or competitors.

Like the US, China has increasing presence in Africa in cultural, economic, and military domains. In an article published on October 24, 2018, Michael Kovrig of the International Crisis Group wrote:

In his address to the 2015 UN General Assembly, China’s President Xi Jinping offered \$100 mn in military assistance over five years to support the AU's peace and security architecture through initiatives such as the African Standby Force and African Capacity for Immediate Response to Crises. The 2015 FOCAC summit in South Africa reinforced this commitment. In Xi's keynote address to this year's forum and in its ensuing plan of action, China pledged to channel some of that funding into a China-Africa Peace and Security Fund, military assistance and 50 programs in law and order, peacekeeping, anti-piracy, and counterterrorism. ${ }^{11}$

The dialectic of power between the US and China, as a central feature of the current international arena, is an illustration that physical boundaries do not reflect virtual boundaries based on power and influence. The African continent is a surrogate terrain for the US-China global competition. This implies that countries that serve as pawns in such circumstances have less control over their space and time and can be described as the "dying nations" in Lord Salisbury's dichotomy. Beside the US and China, France is another dominant player with a more limited sphere of influence, Francophone Africa.

\subsection{France}

Among other countries that are successful in projecting power and defending national interests beyond their borders is France. Contrary to the US and China that seek global influence through local presence, France's strategy has been to concentrate on local presence in Africa as a steppingstone to project the image of a global power. And unlike the US Empire, France has developed domestic constituencies and a tradition of colonial administration. As a result, Francophone Africa south of the Sahara constitutes a unique case in the history of decolonization where the colonial power decolonized but never left. In a way, those former colonies are virtually an extension of the French territory. As the former French Minister of Foreign Affairs, Jean-Francois Poncet, put it in an address to the French parliament in May 1979:

There is undoubtedly no region of the world where the interests and sentiments of France are so profundly engaged as in Africa. Linked to this neighboring continent by ties of history, geography and culture, and dependent upon it as it is upon Europe for its prosperity and security, France pursues in regard to the continent a policy which is desinterested and courageous. ${ }^{12}$

Certainly, there is a contradiction between, on the one hand, depending on Africa for one's own interests, prosperity, and security and, on the other hand, pursuing vis-à-vis the continent a policy that is desinterested even if courageous. Most importantly, France has managed to maintain a zone of influence without a major challenge from other competing powers. To achieve that, it has develped effective tools, cultural, economic and military.

\subsubsection{Françafrique between France and Africa}

How did France, by a tour de force, manage to move from colonial to post-colonial era while preserving its presence and defending its interests in its African pré carré (private preserve)? Gaullism, that consisted of embedding defiance in cooperation with the US and regarding its policy vis-à-vis its former colonies in Africa. Examples abound.

It started with a clash of visions about the post-World War II era between Franklin Delano Roosevelt (FDR) and Charles de Gaulle. That diversion of visions has affected the relationships between the two countries since then. It has also affected France's policy and military posture in Africa.

\footnotetext{
${ }^{11}$ Michael Kovrig, "China Expands Its Peace and Security Footprint in Africa," October 24, 2018. Retrieved from 24oct18-chinaexpands-its-peace-and-security.pdf on December 10, 2020.

${ }^{12}$ George E. Moose is mentioned in Arms and the Africans: Military Influences on Africa's International Relations, William J. Foltz and Henri S. Bienen (eds.), 1985.
} 
President Roosevelt envisioned a post-WWII era without colonial empires. Flying over West Africa during his trip to Morocco in 1943, he did not assess the colonial realty as a successful enterprise, as least for Africans who were left in misery. That situation presented the communist movement with an opportunity for expansion. He forcefully expressed his opposition to colonization at the 1943 conference of Casablanca and demanded that an end be put to it. In the faceto-face meeting in Casablanca, he communicated directly to Charles de Gaulle and Winston Churchill, along with requesting an unconditional surrender of the Axis countries, his opposition to the continuation of colonization: "I have tried to make clear to Winston — and others [including Charles de Gaulle] — that while we are their allies and in it to victory by their side, they must never get the idea that we're in it just to help them hang on to the archaic, medieval empire ideas," he told his son Elliott (Hamilton, 2016). During the Casablanca conference, extensively described by Nigel Hamilton in his book, Commander in Chief: FDR's Battle with Churchill, 1943 (2016), FDR treated de Gaulle as less than a junior partner in the French colony of Morocco (Churchill was FDR's junior partner and de Gaulle was Churchill's junior partner). De Gaulle never forgot it. ${ }^{13}$

In the post-WWII era, while France was more concerned about maintaining its colonial empire under a new form, the US was more concerned about containing the spread of communism. Hence, on the one hand, the French colonial wars in Indochina (1946-1954) and in Algeria (1954-1962) had no support from the US On the other hand, US' military involvement in Vietnam (1955-1975) was not supported by France. Continuing this trans-Atlantic dispute, the US expressed strong opposition to the French, British and Israeli occupation of the Suez Canal in 1956 after its nationalization by Gamal Abdel Nasser, then President of Egypt. When de Gaulle became President of France (1959-1969), he showed independent and assertive foreign policy, diplomacy and military strategy vis-à-vis the US. The pillars of which were an autonomous nuclear strategy based on the doctrine of Proportional Deterrence, withdrawal from NATO's command structures in1966, and creation of a de facto Franco-African state. In a 1973 speech, the former President of Cote d'Ivoire, Felix Houphoet-Boigny, summarized the complexity of the Franco-African relationships in one word: Françafrique appropriately qualifying the de facto Franco-African state.

Perceived villains in de Gaulle's and his immediate successors' African policy, particularly during the Cold War, were communism, Americanism, and Islamism. Strategic cooperation fully resumed with the Atlantic alliance after France returned to all structures of NATO in 2012 under President Nicolas Sarkozy, after a 46 years of hiatus. Given France's economic and military limitations, that cooperation is needed particularly in the context of Opération Barkhane, the French intervention in Western Sahel.

Like for China and the US, France's overseas territories and influence are backed by economic, military, and cultural ties. The hexagon does not reflect its virtual size because it encroaches on the territories of "dying" nations. Managing hegemonic relationships with non-contiguous territories requires skills and tools to deal with space and to control time to be functional. Like the trident of Poseidon, the tools used are in three domains: two formal agreements (financial and military) and one informal, cultural ties.

\subsubsection{Finance: from CFA to CFA}

The acronym had not changed. CFA monetary zone was created in 1948 to help France control its colonies in Africa. The franc zones (one for West Africa and the other for Equatorial Africa) were maintained after independence. However, the wording changed from Colonies Françaises d'Afrique (CFA) to Communauté Financière d'Afrique (CFA). In this financial arrangement, the franc CFA was pegged to French Franc and, subsequently, to the Euro. As a result, African countries involved had have to deposit $60 \%$ of their foreign currency in a special account in France's Treasury. They needed permission to withdraw money from that account and France had the right of veto. In practice, it means that, although pegged to the Euro, the CFA was administered by France, not by the E.U. With such an arrangement, it was difficult for individual African states to have a monetary policy and impossible to agree on a regional common currency, a long time hope of the Economic Community of West African States (ECOWAS).

In December 2019, the Presidents of Ivory Coast, Alassane Ouattara, and of France, Emmanuel Macron, apparently without consulting other member states, jointly announced the creation of a new monetary unit, the Eco, for the eight West African countries using the franc CFA. The move broke a three-decade long struggle by the fifteen countries of ECOWAS to establish a regional currency of the same name to promote trade and development in the region. While a deposit of foreign currency in a special account in the French treasury and a French representative at local Central Banks are no longer required, the new monetary unit is still pegged to the Euro. That means the economy of Togo is assumed to have the same strength as the economy of Germany. Obviously, the monetary system is too strong for weak economies.

\footnotetext{
${ }^{13}$ Nigel Hamilton in his book, Commander in Chief: FDR's Battle with Churchill, 1943 (2016), p. 120.
} 


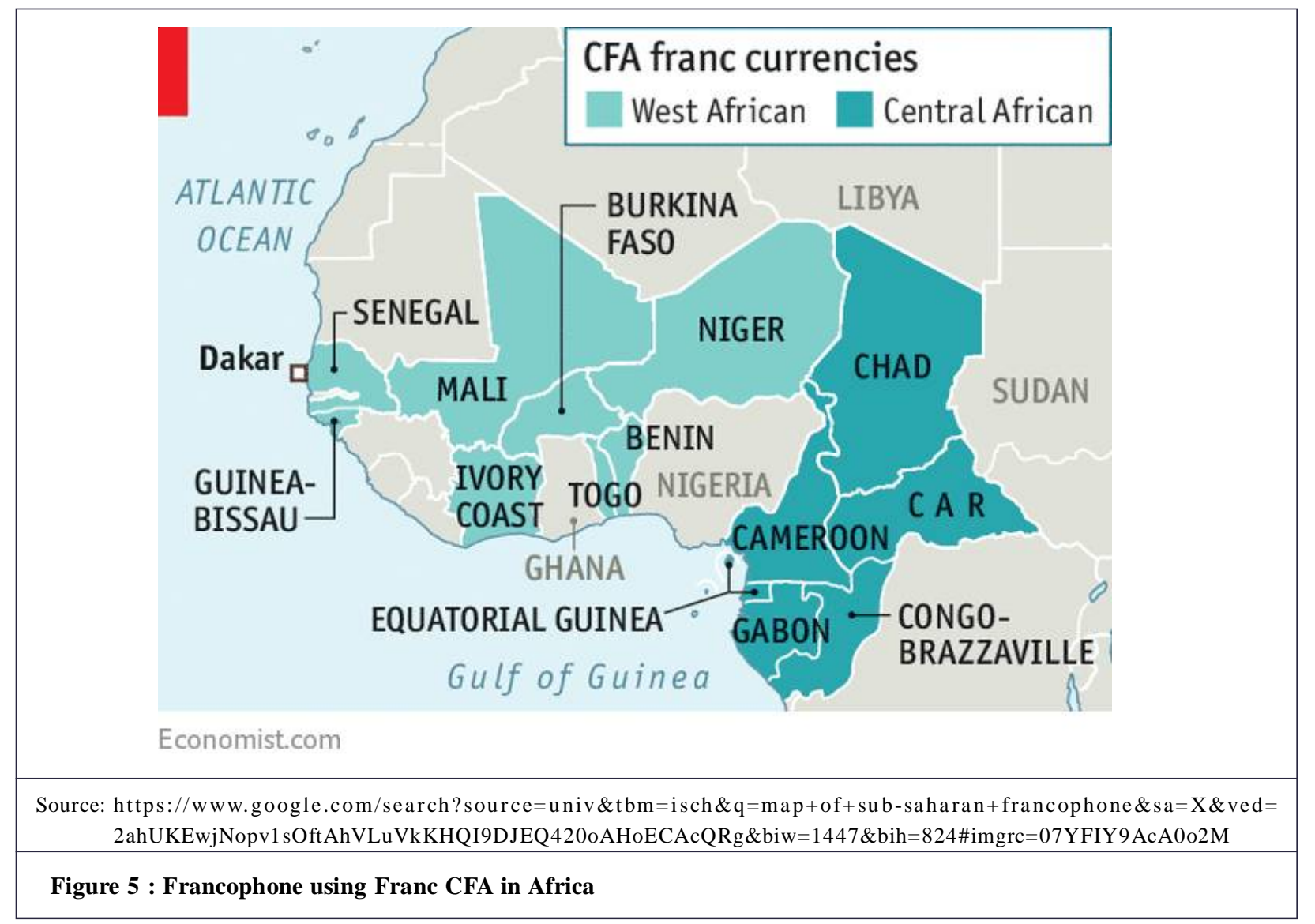

The second pillar of the Franco-African relationships is defense agreements.

\subsubsection{Defense agreements}

The Ministère de la Coopération (Ministry of Cooperation) was created in Paris to manage these agreements with a department for civilian affairs and a department of military affairs. These agreements are bilateral and do not resemble anything like regional pact or collective security organization. Secret clauses in the agreements stipulate that France has priority in purchasing raw materials, from the uranium of Niger to the cocoa of Ivory Coast, in exchange for protection of territorial integrity and national sovereignty of African states parties to the bilateral defense agreements.

\section{Cultural influence}

The cultural influence is also well-organized but, as the same time, less formal. All these agreements are cemented by what can be called a strategy of restructuration á l'identique (recreating identical Frenchman) for African elites. The elites are supposed to be educated in such a way that they could make decisions a metropolitan French leader would normally make, that is without being compelled by France: a quintessential soft power. Therefore, the decisions could be perceived as made by Africans themselves not by Paris. In the words of Johan Galtung (1971) as theorized in his article, "Structural Theory of Imperialism," the elites of the Periphery (local entities) have a harmony of interest with the elites of the Center (metropolis) while the masses of the Periphery have a clash of interest with the masses the Center. Thus, the elites of the Periphery are conceived to perform as the bridgehead of the elites of the Center. That is why the French influence constitutes a structural phenomenon, not just a presence that is salient. Thus, Stephen W. Smith wrote:

Elite cooperation was the cement of the Franco-African state. As a result of its colonial policy of 'assimilation,' Paris has nurtured a sub-Saharan elite of 'black Frenchmen' (women were rarely part of the happy few) who have bought into the normative universalism of French culture and politics. Quite a few had been elected to the French Parliament at a time when 'colored people' in parts of the United States were not allowed to use the same public facilities with whites. ${ }^{14}$

When one combines the cultural, financial, and military ties between France and Francophone African, one should revisit the quotation from J, T. Fraser above: "it is much easier to secure cooperation among people who have no

\footnotetext{
14 Stephen W. Smith, 'France in Africa: A New Chapter,' Current History, May 2013. Stephen W. Smith, ibid. p. 165.
} 
calendars than among people with different calendrical traditions, maintained among other reasons...for the purpose of securing distinct group identities" (Fraser, 2012). This structural dependence is achieved by destroying Africans' calendrical traditions that define their identities and replacing them by time and space (a common social temporality) constructed and controlled by France for the benefit of France.

\section{Challenges to French hegemony}

However, France has been challenged on many fronts. The concept of Françafrique has lost its legitimacy due to three events that occurred in the 1990s: the demise of Houphoet-Boigny of Ivory Coast in 1993 and of the French politician Jacques Foccard (considered the mastermind of Françafrique) in 1997 and, in between, the dubious role played by France during the Rwandan genocide in 1994. The ongoing Opération Barkhane has yet to pacify Western Sahel making some commentators predict a debacle like that of Vietnam. Because of the financial and military limitations of France, it must rely on Western (US in particular) help and on cooperation with local governments, hence the creation in 2017 of G-5 Sahel joint force comprised of Burkina Faso, Chad, Mali, Mauritania, and Niger. The move from Franc CFA to Eco announced in 2019 was made necessary by the harsh criticism from a new generation of Africans.

Boubacar Boris Diop, in a recent article, "Après la pandémie, the réveil de l'Afrique ? "(After the pandemic, Africa awakening?) detected signs that a post pandemic era may be like the post-World War II era in Africa. ${ }^{15}$ The experience on the battlefield revealed the truth about human nature. Africans were demystified (if not disillusioned) about the superiority of their colonial masters. Thus, movements for independence began. According to Diop, Africans learned two important lessons during the covid-19 crisis: how poorly Western countries are managing their own affairs; and how Africans must rely on themselves. Some have shown boldness, compared to the past. Several states including Burundi, Morocco, and Equatorial-Guinea refused to follow, sicut cadaver, the World Health Organization regarding the use of hydroxychloroquine. In Zimbabwe, the US Ambassador was summoned to explain what happened to George Floyd. The President of South Africa declared that the assassination of George Floyd reopened the wounds of Black South Africans, while the Africa Union harshly criticized police brutality against Blacks in the US. China was not spared. There have been official protests against treatment of Black Africans in China which the Ambassador of China was summoned to explained in Abuja, Nigeria. Such bold actions have yet to be seen in former French colonies. However, as noted the Nigerian political scientist, Jibrin Ibrahim, regarding the replacement of the franc CFA by the Eco,

President Macron has been very angry that Sahelians were criticizing his country and ordered the Presidents of the five Sahelian countries to report to Pau in southern France to be told off for not convincing their citizens that France was a good friend. The meeting which was to hold this December [2019] has been postponed to January following the killing of 71 soldiers in Niger by the jihadists. France is therefore using the Eco currency launch as a public relations gimmick to rebuild its battered image. ${ }^{16}$

In light all this dynamic interaction of time and space, one ought to remember the injunction of the poet Aimé Césaire in "Cahier de retour au pays natal" quoted by Diop: "recommencer la fin du monde" (rebuild the end of the world) which sounds like a call for rebirth.

\section{Conclusion}

As Immerwhar (2018) observed, "the tendency of today's borders to stick in place can make the shapes of countries inevitable. The hexagon of France, the stilettoed boot of Italy, the impossibly thin needle of Chile ("as a dagger pointed at the heart of America," quipped Henri Kissinger)—-though they were obviously the result of historical fortune, it's difficult to imagine them taking forms other than the ones they did." 17

Even so, most of the time, one need to imagine the virtual borders beyond the logo maps. As for the three countries discussed, the US, China, and France, their "peri-corporal space," due to their influence, is larger than their internationally recognized boundaries. Management of time is necessary to make sense and use of the space under their control, thus, to build the "social temporality" between the center and the periphery that is meaningful and operational. The de facto Franco-African state is an obvious example.

The coexistence of multiple and competing global powers indicates that it is not necessarily a zero-sum game. Athens and Sparta confronted each other. But China and Ancient Rome never crossed each other, The US and the former Soviet Union confronted each other in a bitter Cold War. But the US displaced and replaced the United Kingdom as global power without a war, not necessarily because of similarity of language and culture, but because the US defeated

15 Boubacar Boris Diop, “Après la pandémie, the réveil de l'Afrique ? “, Le Monde Diplomatique, No. 796 -, Juillet 2020.

16 Jibrin Ibrahim, Deepening Democracy, Daily Trust, 27 ${ }^{\text {th }}$ December 2019.

${ }^{17}$ Immerwhar, ibid. p. 46. 
secondary empires and created space for itself to fill: the Spanish, the Ottoman and the Japanese empires, and the Third Reich. Furthermore, similarity of language and culture has facilitated the transition of the United Kingdom, from dominant power to playing the Greeks vis-à-vis the new Rome, making it easier for the US to transit from major power to global power.

China too has adopted an indirect strategy with three principal pillars: making alliance with countries shunned by the West, creating institutions outside the US' control, building the infrastructure (economic, technological, military, and cultural) for a sustainable "social temporality" with allies, and building a bridgehead between Center and Periphery in Galtung's language. Actual war is not inevitable to achieve China's global ambitions.

There is a difference, however, between US' and China's approaches on the one hand and the French strategy on the other hand. France has developed a tradition of colonial administration (civilian and military) associated with its overseas possessions. That tradition seems not to have died. This is where the way Lord Salisbury qualified the process gains a powerful meaning: "living nations will fraudulently encroach on the territory of the dying" (my emphasis). Given the resistance confronting France with a new generation of Africans, this is also where the words of the poet Diop (1960) resonate: "Les morts ne sont pas morts" (the dead are not dead). ${ }^{18}$

\section{References}

de Unamuno, M. (2014). The tragic sense of life (first published in 1912). Sophia Omni.

Diop, B.B. (2020). Après la pandémie, the réveil de l'Afrique ? Le Monde Diplomatique, No. 796, Juillet.

Diop, B. (1960). Le souffle des ancêtres. Du Recueil des Leurres et Lueurs, Editions Présence Africaine.

Fraser, J.T. (2012). Time the Familiar Stranger. The University of Massachusetts Press.

Galtung J. (1971). Structural Theory of Imperialism, Journal of Peace Research, Sage Publications.

Hamilton, N. (2017). Commander in chief: FDR's battle with Churchill, 1943. Mariner Books.

Hamon, L. (1970). Acteurs et données de l'histoire. Presses Universitaires de France.

Immerwhar, D. (2019). How to hide an empire: a history of the greater United States. New York: Picador.

Kovrig, M. (2018). China expands its peace and security footprint in Africa. Retrieved from 24oct18-china-expands-itspeace-and-security.pdf

Lindquvist, S. (1992). Exterminate all the brutes: one man's odyssey into the heart of darkness and the origins of European genocide (translated by Joan Tate). The New Press.

Moose, G.E., In W.J. Foltz, and H. S. Bienen, (Eds.) (1985), Arms and the Africans: Military Influences on Africa's International Relations. New Haven, CT: Yale University Press.

Rhode, B. (2020). The Spanish question is burning: Living and Dying Nations in 1898. Retrieved from https:// www.belfercenter.org/event/spanish-question-burning-living-and-dying-nations-1898 on December 12.

Rovelli, C. (2018). The order of Time. Riverhead Books.

Smith, S.W. (2013). France in Africa: a new chapter. Current History, May 2013.

Cite this article as: Marcel Kitissou (2021). Reflections on living and dying nations: Space and time in A frica geopolitcs. International Journal of A frican Studies. 1(1), 14-23. doi: 10.51483/ IJAFRS.1.1.2021.14-23.

\footnotetext{
${ }^{18}$ Birago Diop, Le souffle des ancêtres (Du Recueil des Leurres et Lueurs, 1960, Editions Présence Africaine)
} 